\title{
Malnutrition Incidence and Determination of Effecting Factors at 1-4 Years Old Children in Konya
}

\author{
Serap Bati ${ }^{1, *}$ and Fatih Kara ${ }^{2}$ \\ ${ }^{1}$ Konya II Ambulans Servisi KKM Baştabibliği, Kalite Yönetim Birimi, Kalite Yönetim Direktörü \\ ${ }^{2}$ Dept. of Public Health, Selçuk University, Faculty of Medicine, Turkey
}

\begin{abstract}
Background and Aim: Every year in the world millions of children die from malnutrition and infectious diseases. Children under the age of five are affected more quickly than other age groups from negative conditions. This study is aimed to determine the risk factors of malnutrition and incidence of malnutrition in children aged 1-4 years living in Konya.

Materials and Methods: This is a cross-sectional epidemiological study. The survey about demographical information about the child and their family, child's nutrition and anthropometric measurements described by both Z-scoring and GOMEZ classification, was conducted between May-December,2016 with 1000 children aged 1-4 years in Konya province. Descriptive statistics, chi-square test, student t-test and multivariate logistic regression were performed by SPSS 18.0 considering $p<0.05$ as statistically significant.

Results: According to the GOMEZ classification, $18.7 \%$ of children living in Konya are malnourished. According to Zscore, $3.5 \%(n=35)$ of the children were found to be underweight and $7.2 \%(n=72)$ were found as stunted. Factors affecting the malnutrition were the age range of children, the working status of the mother, the kinship status between the parents, the number of living children, maternal age, birth weight, the duration of breastfeeding, the time spent on TV/computer, the attitude and anxiety level of the mother when her child does not eat and the mother's nutrition education.

Conclusion: Malnutrition is a common problem and its rate is high in Konya. It is suggested that health professionals should educate the society, especially mothers by organizing various training meetings. Moreover, it can be emphasized that health planners should prepare a program to determine malnourished children considering the risk factors of malnutrition in health screens and first step medical centers.
\end{abstract}

Keywords: Malnourished child, anthropometric measurement.

\section{INTRODUCTION}

Nutrition is one of the most important factors in the protection and improvement of human health, starting from the mother's womb and getting enough nutrients from the body to grow, develop and maintain a healthy life [1]. Nutrition knowledge examines the most appropriate nutrition plan for individuals with different age, gender, working and special health conditions [2]. It is possible that a society is healthy if the individuals forming the society are healthy. The health of individuals is also dependent on adequate and balanced nutrition [3]. The most important feature that differentiates childhood from other periods is the growth and development process that continues until the completion of adolescence from the beginning of pregnancy. Any factor that disturbs the health status of children in this process may slow down or even stop the growth and development process. Especially during the infancy period, the adverse effects that are exposed due to the markedly high growth rate can cause severe and permanent changes in the growth

*Address correspondence to this author at the Konya III Sağlık Müdürlüğü (B Blok), İhsaniye Mh. Kazım Karabekir Cd. No:12 42060 selçuklu/KONYA; Tel: +903323104000; Fax: +903323517268; E-mail: sserapbati@gmail.com and development process [4]. Malnutrition is a continuing problem among children worldwide. The most medically compromised cases are the fetus during development, children up to the age of five, women in the pre- and post-pregnancy period, and mothers who suckles children [5]. Malnutrition, preventing growth and development, causes many changes in the endocrine system. Since thyroid hormones, insulin, and growth hormone are the most affected hormones, most of the children who are diagnosed with malnutrition also have short stature [6]. Treatment of malnourished children is difficult and long lasting. Treatment should be done in specialized centers. In particular, complications that may occur during the first few days of treatment may be fatal. Problems can not be solved easily by giving sufficient foods to malnourished infants; on the contrary, malnutrition does not heal and even worse in some patients [7]. Worldwide low-pound prevalence is $15.00 \%$, stunting prevalence is $25.00 \%$ and rubidity prevalence is $8.00 \%$. In less developed countries, these rates are $23.00 \%, 37.00 \%$ and $10.00 \%$ respectively. The highest stunting rates for 2015 are in Oceania (38.20\%), East-Central-West Africa (37.50\% $31.20 \%-32.10 \%)$. The lowest prevalence is in Australia $(2.00 \%)$, North America $(2.10 \%)$, East Asia 
$(6.00 \%)$ countries [8]. When the data between 1993 and 2013 belonging to TDNS (Turkish Demographic and Health Survey) are compared, the decrease in $\mathrm{H}-\mathrm{A}$ (stunting), $\mathrm{W}-\mathrm{H}$ (undergrown) and $\mathrm{W}-\mathrm{A}$ (underweight) score rates is noteworthy. The stunting rate, which was $19.10 \%$ for women and $18.70 \%$ for men in 1993 , declined to $10.90 \%$ for women and $8.00 \%$ for men in 2013. The most significant decline is seen in the low weight ratio [9].

The main topics in malnutrition etiology can be expressed as the inadequate consumption of energy and nutrients, inadequacy of environmental health conditions, socio-cultural factors related to nutrition, birth or later diseases [5]. The aim of this study is to determine the incidence of malnutrition and factors affecting malnutrition in children aged 1-4 years in Konya, one of Turkey's greatest provinces.

\section{MATERIALS AND METHODS}

\section{Sampling Design}

The study population was 135,659 children aged 14 years living in Konya. By population-based cluster sampling method, which is popular for large geographical regions, which units included in the cluster sampling. (Village, neighborhood, district) with $80 \%$ power and $5 \%$ type-I error, 942 what is the reference value taken in sample size calculation children were identified by using sample size method for one-sample proportion [10] and it was aimed to reach 1000 children in order to have more power and precision. Since there is no study about the prevalence of malnutrition in Konya, the study of İnanç et al. on which the rate was given as $20 \%$ [11]. Desing effect was considered as 2 and cluster size was determined as 25. In this case, the number of clusters was 40 $(\sim 1000 / 25=40)$ and total population was divided by this number to determine the sample interval. The districts of Konya province and the neighborhoods of the districts were stratified according to the weighted populations. Therefore, the places were determined by simple randomized sampling method. As a result, Selçuklu, Meram, Karatay, Ereğli, Akşehir, Beyşehir and Çumra districts were choosen to apply the survey.

\section{Study Design and Ethics}

The study was a cross-sectional and epidemiological study conducted using a 7-part questionnaire. The ethical approval of the research was obtained by the decision of the Ethics Committee of
Konya Selcuk University, Medical Faculty on 02.02.2016 and numbered 2016/35, and also a written consent was obtained from the Konya Public Health Directorate.

\section{Participants, Data Collection and Measurements}

In the prepared questionnaire, there are 69 questions including demographic data, family information, birth history, nutrition habits, health status, life style and andropometric measurement results. Z scoring and GOMEZ classification were used in the evaluation of the andropometric indicators. Height and weight measurements of 24-month-old children were measured with baby height scales (EKS-8006 VI-VI), height and weight measurements of 24 months old children with height scale (Charder MS-3400) and the thickness of the skin folds was made with a caliper device (Holtain Skinfold Caliper).

\section{Statistical Analysis of Data}

Analysis of the data was performed using SPSS 18.0 (IBM Inc., IL, USA). Categorical data were presented as percentage and frequency, numerical data as mean \pm SD. Student t-test was used when parametric conditions were met for group comparisons, and Mann-Whitney $U$ test was used when not. A logistic regression model was developed for the variables with significant differences between the groups. $P$ value of less than 0.05 was considered statistically significant.

\section{RESULTS}

The rate of girls of participants was $47.40 \%$ (474). The month intervals were $9.10 \%$ (91) for $13-17$ months, $15.10 \%$ (151) for $18-23$ months, $34.10 \%$ (341) for 24 35 months, $24.40 \%$ (254) for $36-47$ months and $16.30 \%$ (163) for 48-59 months respectively. The average age of the mothers was $30.40 \pm 5.43$ years and the average age of their fathers was $33.93 \pm 6.00$. $98.70 \%$ (987) of participants were married and $90.70 \%$ (907) of the mothers were housewives. $10.10 \%$ of the families (101) expressed their socio-economic status as poor, while $94,50 \%$ of the fathers (945) were working in a job. $77.90 \%$ (779) of the families were elementary and $7.70 \%(77)$ of the parents had first degree kinship relationship.

$9.30 \%(93)$ of the mothers had chronic disease. $10.80 \%(108)$ of the mothers were smoking and none of them had an alcohol/substance addiction. 
Sufficiency of prenatal care was evaluated in the study. Pre-natal care was considered inadequate for those who went to family physicians 4 times less during pregnancy. $70.60 \%$ of the women (706) had adequate antenatal care. Mothers participating in the study stated that $84.50 \%(845)$ of multivitamines, $81.40 \%(814)$ of iron and $80.00 \%(800)$ of vitamin D were regularly used by mothers during the pregnancy for participating children.

$36.30 \%$ (363) of the mothers stated that they were educated about child nutrition and $63.70 \%$ (673) said that they did not receive education on nutrition. Educated mothes stated that they took $66.94 \%$ (243) from family physicians, $18.45 \%$ (67) from friends, $17.07 \%$ (62) fromTV/radio, $22.04 \%$ (80) from the internet, $21.21 \%$ (77) from experience, $16.53 \%$ from books (60), and $6.06 \%$ (22) from magazines and newspapers. $85,90 \%$ of the mothers (859) stated that they gave first breast milk after birth to the child. The food served out of the breast milk were $78.72 \%$ (111) of formula food, $15.60 \%$ (22) of sugary water, and the others were expressed as zemzem, date water, soda (mineral water) and cow milk. Of the 141 mothers who did not give breast milk to their children for the first time, $83.00 \%$ (117) of them stated that they did not have lactation and $17.00 \%$ (24) of them stated that their children did not sucked. It was found that $38.31 \%$ (54) of 141 mothers breastfed the baby within 6-12 hours, $12.10 \%$ (17) within $12-24$ hours, $41.80 \%$ (59) after 1 day, $7.80 \%$ (11) had never breastfed. There was no significant relationship between mother / father BMI and education status and low weight $(p=0,478 / 0,738$ and $p=0,897 / 0,951$ respectively). There was also no significant relationship between birth weight and low birth weight $(p=0.869$ and $p=0.478)$. Children who were given nutrients in the first 6 months apart from breast milk were lower than those who only received breast milk $(p=0.037)$.

$29.61 \%$ (291) of the 986 mothers who answered "which supplementary food was given to baby first?" question, $29.40 \%$ (290) of them answered as yogurt and $22.80 \%(225)$ as soup. It was stated that $58.20 \%$ of the parents (528) eat regularly at the same time every day, $35.60 \%$ (356) eat time can change and $6.20 \%$ (62) eat everybody when they are hungry. According to $Z$ scoring, $3.50 \%$ (35) of the children aged 13-59 months were low weighted and $7.20 \%$ (72) squats. $4.40 \%$ (44) were malnourished according to the head circumference, $3.10 \%$ (31) according to the circumference, $0.10 \%$ (1) triceps according to the skin fold thickness. 536 mothers suckled their child for less than 2 years since $40.90 \%$ of them (219) have not enough milk, $18.70 \%$ of them (100) went to supplementary feed, in $23.50 \%$ (126) did not suckle the children, $11.60 \%(62)$ of them were pregnant again and $4.90 \%$ of them (26) stated that she could not breastfeed her child because of illness.

According to the results of the logistic regression analysis on Z scoring, birth weight, mother's attitude when the child does not eat, mother's nutrition education status and the time spent on TV/computer are the factors affecting the weight score (Table 1). Low birth weight and much spent time were risk factors for malnutrition, and unforcing attitude of mother and having more educated level of mother were preventive factors for malnutrition.

According to the results of the logistic regression analysis on GOMEZ scoring, the birth weight and sister body growing were found as significant factors (Table 2). Low birth weight and lagging growth of sister body effect the malnutrition as a risk factor.

Table 1: Factors Affecting Malnutrition According to Z Scores

\begin{tabular}{|c|c|c|c|c|c|}
\hline $\begin{array}{l}\text { Model Information }{ }^{1} \text { : } \\
R^{2}=0.073, p=0.008\end{array}$ & Beta & $p$ & OR & \multicolumn{2}{|c|}{$95 \% \mathrm{Cl}$} \\
\hline Only breast milk in first 6 months & -.592 & .140 & .553 & .252 & 1.214 \\
\hline Sister body growing & .719 & .117 & 2.053 & .836 & 5.043 \\
\hline Birth weight & 1.422 & $.006^{*}$ & 4.144 & 1.504 & 11.422 \\
\hline Birth time & .471 & .358 & 1.601 & .587 & 4.366 \\
\hline Anxiety level of mother & .056 & .710 & 1.058 & .787 & 1.423 \\
\hline Attitude of mother in serving food & -.576 & $.004^{*}$ & .562 & .378 & .835 \\
\hline Education status of mother on malnutrition & -1.353 & $.017^{*}$ & .259 & .085 & .788 \\
\hline Spent time of child on TV/computer & .323 & $.027^{*}$ & 1.381 & 1.038 & 1.837 \\
\hline
\end{tabular}

${ }^{1}$ Reference Category: No malnutrition, *: significant result at 0.05 level. 
Table 2: Factors Affecting Malnutrition According to GOMEZ Scoring

\begin{tabular}{|c|c|c|c|c|c|}
\hline $\begin{array}{l}\text { Model Information }{ }^{1} \text { : } \\
R^{2}=0.096, p<0.001\end{array}$ & Beta & $p$ & OR & \multicolumn{2}{|c|}{$95 \% \mathrm{Cl}$} \\
\hline Birth weight & 1.273 & $<.001^{*}$ & 3.573 & 2.088 & 6.112 \\
\hline Birth time & -.115 & .640 & .892 & .551 & 1.441 \\
\hline Order of birth & -.031 & .805 & .969 & .757 & 1.241 \\
\hline Sister body growing & .946 & $<.001^{*}$ & 2.575 & 1.610 & 4.117 \\
\hline Working status of mother & .952 & .052 & 2.590 & .993 & 6.754 \\
\hline Education status of mother on malnutrition & -.332 & .094 & .718 & .487 & 1.057 \\
\hline Number of living children & -.006 & .959 & .994 & .789 & 1.252 \\
\hline
\end{tabular}

${ }^{1}$ Reference Category: No malnutrition, *: significant result at 0.05 level.

\section{DISCUSSION}

Malnutrition is one of the main causes of child mortality. According to WHO's description, an average of 13 million children per year in the world die before they reach the age of 5 and the basic cause of about one third of all child's deaths is malnutrition. The relative mortality risk for severe malnutrition is reported to be $8.4,4.6$ for moderate malnutrition, and 2.5 for mild malnutrition [10]. The presence of malnutrition contributes $60.00 \%$ of child mortality. This effect is more pronounced in young children. Malnutrition increases at least twice the risk of diarrhea, respiratory diseases and death from measles. More importantly, more than $80 \%$ of malnutrition-related deaths occur in children with mild to moderate malnutrition [11]. In some industrialized countries, the decline in social assistance with increasing income inequalities had a negative impact on children's nutritional health. The risk of malnourished children dying from widespread pediatric diseases is much higher than for adequately fed children [12]. In infants with malnutrition, infectious diseases are more common and severe. The four most important causes of death in young children worldwide are diarrheal diseases, pneumonia, measles and malaria. It is reported that these diseases have a significant effect on nutritional deficiency in deaths, contributing to death by more than $50 \%$ of child deaths. A child with malnutrition is more easily infected with infectious diseases than other children [13].

In our study, the gender percentages was similar and the greatest ratio of age belonged to 24-35 months. Income level of the families was moderate and nearly half of the parents were overweighted. The average age of the parents was considered to be midaged. The incidence of malnutrition according to was found to be low weight as $3.50 \%$, stunting rate $7.20 \%$, malnutrition rate per head circumference as $4.40 \%$, malnutrition rate per arm circumference as $3.10 \%$, and per triceps skin fold thickness as $0.10 \%$. In a study conducted in China in 2009, the low weight gain was found to be $4.50 \%$ [14]. In Ethiopia 219 children under five years of age, stunting rate was found to be $57.10 \%$, low weight $37.40 \%$ and weakness $17.80 \%$. Low weight was found to be lower in children aged 30 41 months than in children aged 50-59 months [15]. There were $74.90 \%$ (161) mild, $25.10 \%$ (54) moderate and none severe malnourished children per GOMEZ classification of 1-5 years old who applied to the Child Gastroenterology, Hepatology and Nutrition Polyclinic in Selçuk University Faculty of Medicine [16]. It was determined that $0.90 \%$ (9) of the children severe, $3.70 \%$ (37) moderate and $14,10 \%$ (141) mild malnutrition in GOMEZ evaluations in our study. The median duration of breastfeeding for all children born within three years preceding TDHS-2013 is 16.70 months. Although breastfeeding is common in Turkey, only breastfeeding in children is $42.00 \%$ in TDHS-2008 and $30.00 \%$ in TDHS 2013. Therefore, only breastfeeding is not commonly practiced. According to TDHS 2013, the median duration of breastfeeding in rural areas (17.90 months) is longer than in urban areas (16.40 months). In a study conducted with 5003 mothers in Izmir, the average duration of breastfeeding only was $4.30 \pm 2.10$ months and the rate of breastfeeding was low in families with single child and high socioeconomic level [17]. In a study conducted in Nigeria, it was found that children who breastfeed for longer than 12 months tend to be more stunted than children who breastfeed for less than 12 months [18]. In our study, it was found that there is a significant difference in the low weight ratio of children who received only breast milk for the first 6 months and children who took supplementary food or did not breast-feed in early period. In a study with 251 mothers in Samsun, the starting time for supplementary food 
was found to be $2,04 \pm 0,04$ months. In the same study, the reason for starting early supplementary food was determined as unwillingness to suckle baby $(34.20 \%)$ and lack of lactation (32.90\%) [19]. In our study, 11 mothers have never suckled their children. Of 989 parents who suckle the child, $22.90 \%$ had less than 1year duration, $7.00 \%$ had 1 year, $24.40 \%$ had 1 2 years, $22.90 \%$ had 2 years, $11.30 \%$ had more than 2 years sucked her babies. The mothers who suckle the child for less than 2 years stated that they did not suck because of lack of lactation (40.90\%), starting supplementary food $(18.70 \%)$, unwillingness suckle of baby $(23.50 \%)$ and again pregnancy $(11.60 \%)$. According to TDHS 2013, the incidence of malnutrition was found to increase with births of 6 and over. In a study conducted with 560 children in Kayseri, it was found that the children after the third child were 1.70 times more risky in terms of malnutrition (H-A) [11]. In Navdar's study, the single-child family found similarities in the frequency research and control group. There was no difference between the research and control groups on the assessment that the age difference between the brothers was less than 2 years [18]. In a study conducted in Bangladesh, more malnutrition was seen in those who had births less than 2 years with more than 5 births [15]. In a study with 882 children in Pakistan, it was found that the risk of malnutrition increased because of more interest and spared time for the first children. We found a similar result with the literature that low birth weight and sister body growing were significant factors affecting malnutrition [20-24].

\section{CONCLUSION}

Early diagnosis and treatment are important in malnutrition. It should not be overlooked that malnutrition can be diagnosed with light and medium malnutrition which can be prevented by means of health staff working in the first step medical centers. The rate of malnourished children living in Konya is about $19 \%$ according to GOMEZ classification. Stunting and underweighting are also important problem in those children. Low birth weight, sister body growing, increasing in the number of sister, eating of child alone in the table are seem to be affecting factors of malnutrition. Guidelines that are continually updated to prevent malnutrition and that are appropriate to the circumstances of the country should be developed, implemented and the results of this practice assessed regularly. In order to reduce the health problems caused by genetic factors, it is very important that genetic counseling services take place in primary health care services and genetic counseling services are given to individuals who have malnutrition in their family One of the most important risk factors for low birth weight is a low weight born before. Therefore, these kinds of factors should be screened carefully. Malnutrition resulting from the inability of infants to start appropriate supplemental food can have irreversible consequences in later life. As in all periods of life, children need healthy and regular nutrition during early childhood. Children should be allowed to eat on their chair in the dinner table for at least ten minutes and eat by theirselves.

\section{REFERENCES}

[1] Koletzko B. Basic Concepts Nutrition: Nutritional needs of children and adolescents. e-SPEN the European e-Journal of Clinical Nutrition and Metabolism 2008; 3: 79-184. https://doi.org/10.1016/j.eclnm.2008.04.007

[2] Baysal A. Beslenme.11th ed. Hatipoğlu Yayınevi 2009.

[3] Köksal E. Beslenme ve Bilişsel Gelişim. Sağlık Bakanlığı Yayınları 2008.

[4] Black RE, Allen LH, Bhulta ZA, Chaulfeld LE, Onis M, Ezzati $M$, et al. Maternal and child undernutrition: Global and regional exposures and health consequences. Lancet 2008; 371(9608): 243-60. https://doi.org/10.1016/S0140-6736(07)61690-0

[5] Güler Ç, Akın L. Halk Sağlığı Temel Bilgiler. Hacettepe Üniversitesi Yayınları 2015; pp. 412-418.

[6] Saner G, Durmaz Ö, Gökçe S. Beslenme durumunun değerlendirilmesi. In: Pediyatri, Neyzi O, Ertuğrul T. 4th ed. Nobel Tıp Yayınevi 2010; pp. 233-238.

[7] Özen $H$. Protein enerji malnutrisyonu. In:Çocuk Gastroenteroloji, Hepatoloji ve Beslenme, Özen H, Yüce A Gürakan F, Temizel İN, Demir H. 2nd ed. Akademi Yayınevi 2013; pp. 387-397.

[8] UNICEF: Level and Trends in Child Malnutrition. https://www.unicef.org/media/files/JME_2015_edition_Sept_ 2015.pdf (2015). Accessed Apr, 182016.

[9] HÜNEE: Hacettepe Üniversitesi Nüfus Etüdleri Enstitüsü Türkiye Nüfus ve Sağlık Araştırması. http://www.hips. hacettepe.edu.tr/tnsa2013/rapor/TNSA_2013_ana_rapor.pdf (2013). Accessed Apr, 232016

[10] Dawson B, Trapp RG. Basic \& Clinical Biostatistics, 1994, 2nd Ed., USA, Appleton\&Lange Publ.

[11] İnanç N, Aykut M, Çiçek B, Şahin H, Yılmaz M, Katrancı D, et al. Kayseri il merkezinde 0-36 aylık çocuklarda malnutrisyon durumu ve etkileyen bazı faktörler. Türk Hijyen ve Deneysel Biyoloji Dergisi 2005; 62: 41-48.

[12] Jamro B, Junejo AA, Lal S, Bouk G, Jamro S. Risk factors for severe acute malnutrition in childrenundertheage of five year in Sukkur. Pak J Med 2012; 51(4).

[13] Ubesia AC, İbeziako NS, Nidiokwelu Cl, Uzoka CM, Nwafor CA. Under-five protein energy malnutrition admitted at the University of Nigeria Teaching Hospital, Enugu: a 10 year retrospective review. Nutrition Journal 2012; 11(1): 2-7. https://doi.org/10.1186/1475-2891-11-43

[14] Senbanjo IO, Olayiwola IO, Afolabi WA. Dietary practices and nutritional status of under-five children in rural and urban communities of Lagos State, Nigeria. Niger Med J 2016; 57(6): 307-313.

https://doi.org/10.4103/0300-1652.193854

[15] Rahman A, Chowdhury S. Determinants of chronıc malnutrition among preschool children in Bangladesh. J Biosocsci 2007; 39: 161-73. https://doi.org/10.1017/S0021932006001295 
[16] Qu P, Mi B, Wang D, Zhang R, Yang J, Liu D, Dang S, Yan $\mathrm{H}$. Association between the Infant and Child Feeding Index (ICFI) and nutritional status of 6- to 35-month-old children in rural western China. PLoS ONE 2017; 12(2): 1-14. https://doi.org/10.1371/journal.pone.0171984

[17] Tamiru MW, Tolessa BE, Abera SF. Under nutrition and associated factors among under-five age children of kunama ethnic groups in tahtay adiyabo woreda, tigray regional state, ethiopia: community based study. International Journal of Nutrition and Food Sciences 2015; 4(3): 277-288. https://doi.org/10.11648/j.ijnfs.20150403.15

[18] Navdar S. Konya ilinde selçuk üniversitesi tıp fakültesine başvuran 1-5 yaş grubu çocuklarda protein-enerji malnütrisyonunun risk faktörleri. Trainer Dissertation (2016). Selçuk UniversityMedical Faculty, Pediatrics Dept., Konya, Türkiye.

[19] Ünsal N. Türkiye'de 5 yaş altı çocuklarda görülen malnutrisyonun belirleyicileri. Master dissertation (2006). Hacettepe University Institude of Population Studies, Sociology Dept., Ankara, Türkiye.

[20] Akombi BJ, Agho KE, Hall JJ, Merom D, Burt TA, Renzaho AM. Stunting and severe stunting among children under-5 years in Nigeria: A multilevel analysis. BMC Pediatrics 2017; 17(15): 2-16.

https://doi.org/10.1186/s12887-016-0770-z

[21] Tunçel EK, Dündar C, Canbaz $S$, Pekşen Y. Bir üniversite hastanesine başvuran 0-24 aylık çocukların anne sütü ile beslenme durumlarının saptanması, CU Hemşirelik Yüksekokulu Dergisi 2006; 10(1): 1-6.

[22] Batool R, Butt SM, Tauseef S, Saeed F, Naz R. ProteinEnergy Malnutrition: A Risk Factor for Various Ailments. Critical Reviews in Food Science and Nutrition 2013; 55: 242-253.

https://doi.org/10.1080/10408398.2011.651543

[23] Seçil AK. Gestasyon haftasına göre düşük doğum ağırlığıyla doğan bebeklerin büyüme sürecinin izlemi ve morbiditelerinin değerlendirilmesi. Uzmanlık Tezi, İstanbul Üniversitesi Çocuk Sağlığı Enstitüsü, İstanbul 2012.

[24] Low JA, Galbraith RS, Muir D, Killen H, Pater B, Karchmer J. Intrauterine growth retardation: a study of long-term morbidity. Am J Obstet Gynecol 1982; 142: 670-677. https://doi.org/10.1016/S0002-9378(16)32439-5 